\title{
MONITORING SURVEY OF ANTIBIOTIC SENSITIVITY IN CHILD URINARY SYSTEM INFECTIOUS AGENTS (EXPERIENCE IN STAVROPOL)
}

\author{
Medvedeva A. N., Kalmykova A. S.
}

\author{
Stavropol State Medical University, Russian Federation
}

N umerous studies show that microbial inflammatory diseases in urinary system rate second among childhood infections. The relapsing course of infection in children may result in urinary tract obstruction and chronic renal failure. This makes microbial kidney issues the most common reason behind chronic renal failure in children. The latest years have witnessed an increase in the relative share of urinary tract infections (UTI) in the overall morbidity pattern in children (from 18 to 36-100 per 1.000 of child population) $[2,5,6]$.

A key to success for treating UTI in children is antibiotic therapy provided started in due time and in view of the sensitivity of pathogens. Initial antibiotic treatment in most cases is administered prior to the identification of the pathogen, i.e. speculatively $[9,12]$, which means it is based on the knowledge of the characteristics pertaining to the most likely pathogens causing UTI, and their potential sensitivity to the medicine prescribed.

The latest decade, given the impact of various factors (accelerating mutation of microorganisms; alterations in the immunity; widespread, yet not always well grounded use of antibiotics) has seen certain changes in the structure and properties of the infectious agents causing pyelonephritis in children; a growth in the mixed infections, as well as the development of microbial flora resistance to the chemotherapeutic agents so widely used previously $[1,8,10]$.

As many researches suggest, gram-negative bacteria of the Enterobacteriaceae family (80.6\%): Escherichia coli, Proteus spp., Klebsiella spp., etc. are the most prevalent in the spectrum of infectious agents causing UTI in children. Various authors point that the detection frequency for $E$. coli varies between $41.3 \%$ and $83.3 \%[2,7,8,10]$. However, there is data from local studies stating that staphylococcal microflora (32.3 \%) prevails over Escherichia (19.4\%) [1].

The structure of other uropathogens in different parts of Russia also has some specific features [1,

Medvedeva Anastasia, MD, Junior Lecturer, Department of Child Disease Propaedeutics, Stavropol State Medical University; tel.: (8652)232107 (w), 89197461147 (mob) e-mail: anzagrubina@mail.ru

Kalmykova Angelina, MD, PhD, Professor; Head of Department of Child Disease Propaedeutics, Stavropol State Medical University tel.: (8652)232107 (w), 352970; e-mail: kangeline@mail.ri
$24,7,8,10-12]$. This means a need for regular regional microbiological monitoring as being aware of an up-to-date list of infectious agents behind microbial inflammatory diseases in the urinary system of children within a particular region would allow developing a timely and differentiated approach to administering an adequate empirical antibiotic therapy even before the urine culture results are available.

The purpose of this study is to investigate the specific features about the up-to-date list of infectious agents and the antibiotic sensitivity in UTI-causing pathogens in children of Stavropol (Russia).

Material and Methods. We observed 220 children aged 1 month to 5 years with acute community acquired infections of the upper and lower urinary tract, who were staying at the Nephrological Department of the Philippsky Child Clinical Hospital of Stavropol. All the children went through microbiological examination of urine, which implied determination of the degree of bacteriuria, verification of the isolated pathogen, and detection of the sensitivity to antimicrobial agents.

$177(80.5 \%)$ out of the 220 children were girls, the rest of them $-43(19.5 \%)$ - being boys. All the children were divided into 3 age groups: Group I under 1 year; Group II - 1-3 years, and Group III 3-5 years.

The statistical analysis of the study results was performed using Microsoft Excel software whereas the statistical significance was calculated using Student's t-test; Fischer's method was employed to determine the confidence limits of shares (per cent) [3].

Results and Discussion. In Group I the boys accounted for $31.3 \%$ of the population with the girls being in the majority $-68.7 \%$ (boy/girl ratio - 1:2). $29(43.3 \%)$ children of this group were diagnosed with urinary tract infection (UTI); 26 (38.8\%) children had acute secondary obstructive pyelonephritis (PN), with another 12 (17.9\%) having acute undifferentiated PN.

In the group aged 1-3 yrs the boys/girls ratio was $1: 4.5$ (18.2 \% vs. $81.8 \%)$. Given the nosological structure, those with acute secondary obstructive PN (58\%) were in the majority; UTI was observed in $27(30.7 \%)$ children; acute undifferentiated PN in $9(10.2 \%)$ children, and one of the children was 
diagnosed with acute secondary dysmetabolic PN. Group III had 59 (90.8 \%) girls and 6 (9.2\%) boys, the ratio of boys vs. girls being 1:10 respectively. Acute secondary obstructive $\mathrm{PN}$ was on the top in the morbidity pattern in the children aged 3-5 yrs $(76.9 \%)$; children with UTI here accounted for $13.8 \%$, and those with acute undifferentiated PN $9.2 \%$ (Fig. 1).

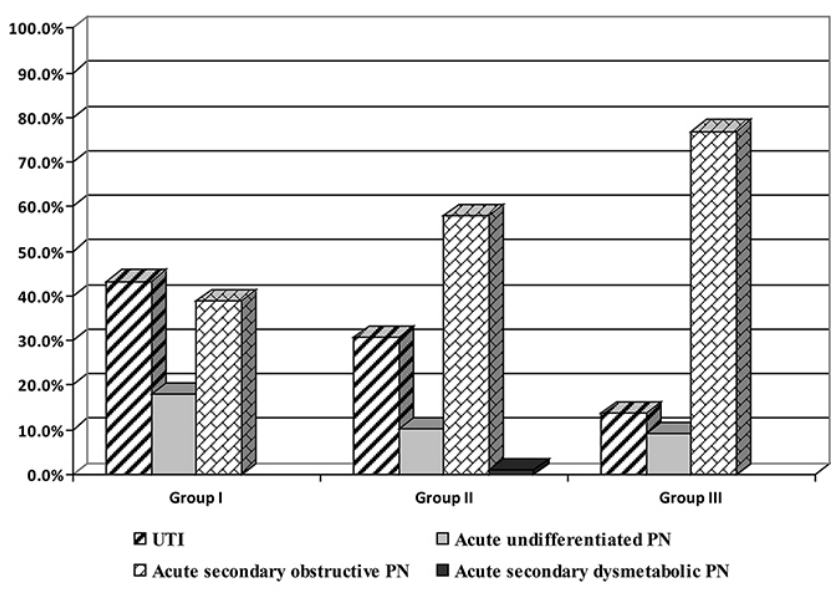

Fig. 1. Pattern of UTI morbidity depending on age

Following the data obtained, diagnostically significant bacteriuria $\left(\geq 10^{5} \mathrm{CFU} / \mathrm{ml}\right.$ ) was registered in $80.6 \%$ cases in Group I, while the rest of the group's population had non-significant bacteriuria $\left(\leq 10^{4} \mathrm{CFU} / \mathrm{ml}\right)$. The children of Group II showed a high rate of bacteriuria in $59.1 \%$ of cases, and in Group III this index was $36.9 \%$.

The results being negative could by largely due to the fact that the urine culture test was performed after the initiation of antibiotic therapy.

Based on the results of our study, the major causative agents for the community acquired UTI in all the groups were bacteria of the Enterobacteriaceae family, E. coli predominantly (Fig. 2a). In Group I (Fig. 2b) their share in the etiological structure was $88.9 \%$, including $11.1 \%$ that had microbial associations with other pathogens (the most common association was Enterobacteriaceae + Str. faecalis association). Other uropathogens were verified much more rarely. Str.faecalis, for instance, was detected in $18.5 \%$ of the children in the group in question, while in $14.8 \%$ of mixed infection cases it was a second or a third microorganism.

The third most common UTI agent in children aged under 1 was Candida spp. separately and its associations with other pathogens $(7.4 \%)$. In the group aged 1-3 (Fig. 2c) the uropathogens related to the Enterobacteriaceae family were found in $96.2 \%, 11.6 \%$ of them being identified as a mixed infection. The second most common, just like in Group I, was Str. faecalis separately and its associations (11.6\%), the third most common coming Pseudomonas (3.9\%).

In Group III (Fig. 2d) the proportion of the Enterobacteriaceae family was somewhat lower than in the two other groups (83.4\%), while Str. faecalis was verified 1.8-2.9 times as often (33.4\%); $8.3 \%$ children of this group were found to have Staph.aur. associated with Enterobacteriaceae и Str. faecalis.
Pattern of UTI agents depending on age of the children

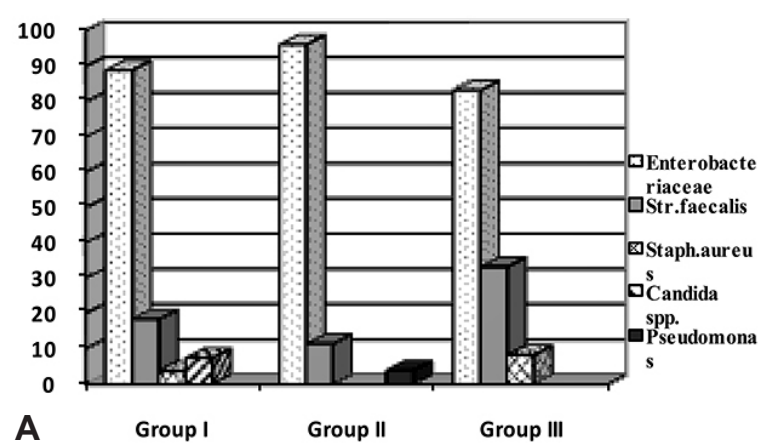

Pattern of UTI agents in children aged under 1

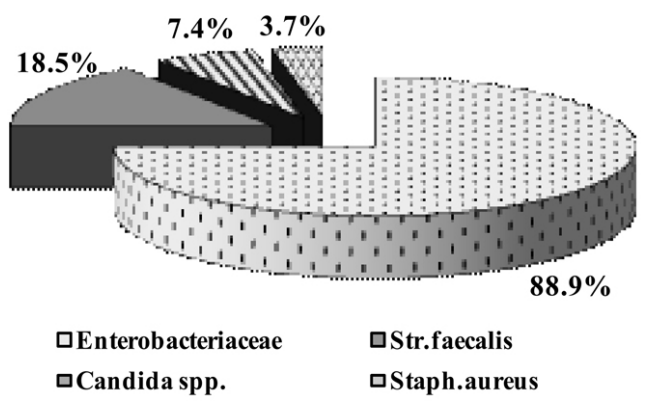

Pattern of UTI agents in children aged 1-3

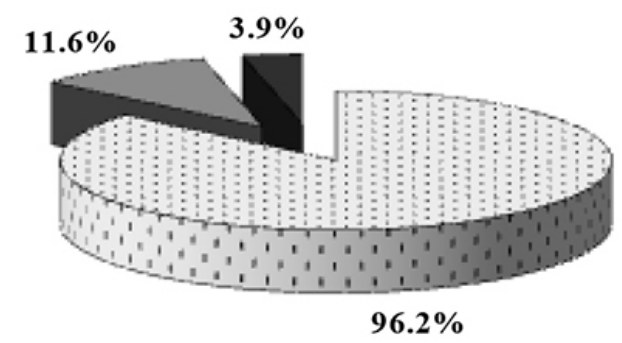

๑Enterobacteriaceae $\square$ Str.faecalis $\square$ Pseudomonas

Pattern of UTI agents in children aged 3-5

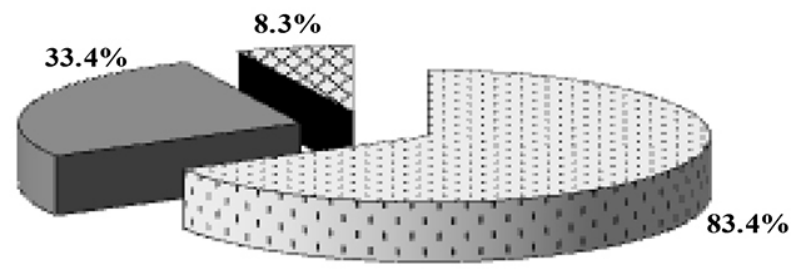

DEnterobacteriaceae $\square$ Str.faecalis ÐStaph.aur.

Fig. 2. Pattern of UTI agents depending on age 
In the group of children aged below 1 (Table), the pathogens of the Enterobacteriaceae family revealed the highest sensitivity to Ciprofloxacin (83.3\%), Ceftazidime (79.2\%), Cefotaxime (70.8\%), Cefoperazone (70.8\%), Cefepime (70.8\%), Amoxiclav (66.7\%), Meropenem (66.7\%), Furadonin (66.7\%), and Gentamicin (62.5\%). At the same time $70.8 \%$ of them proved resistant to Ampicillin, $50.0 \%$ - to Amoxicillin, $45.8 \%$ - to Oxacillin, $37.5 \%$ - to Cefazolin and Laevomycetin, $33.3 \%$ - to Gentamicin, Biseptol, Vancomycin and Palin.

Table

Antibiotic sensitivity in the major UTI pathogens depending on children's age (\% of sensitive strains)

\begin{tabular}{|c|c|c|c|c|c|c|}
\hline \multirow[b]{2}{*}{ Drugs } & \multicolumn{2}{|c|}{ Group I } & \multicolumn{2}{|c|}{ Group II } & \multicolumn{2}{|c|}{ Group III } \\
\hline & $\begin{array}{c}\text { Entero- } \\
\text { bacte- } \\
\text { riaceae } \\
\mathrm{n}=48\end{array}$ & \begin{tabular}{|c|} 
Str. \\
faeca- \\
lis \\
$\mathrm{n}=10$ \\
\end{tabular} & $\begin{array}{c}\text { Entero- } \\
\text { bacte- } \\
\text { riaceae } \\
\mathrm{n}=50\end{array}$ & \begin{tabular}{|c|} 
Str. \\
faeca- \\
lis \\
$\mathrm{n}=6$ \\
\end{tabular} & $\begin{array}{c}\text { Entero- } \\
\text { bacte- } \\
\text { riaceae } \\
\mathrm{n}=20\end{array}$ & $\begin{array}{c}\text { Str. } \\
\text { faeca- } \\
\text { lis } \\
\mathrm{n}=8\end{array}$ \\
\hline Ampicillin & 16.7 & 80.0 & 20.0 & 100.0 & 20.0 & 75.0 \\
\hline Amoxicillin & 29.2 & 60.0 & 48.0 & 66.7 & 40.0 & 75.0 \\
\hline Amoxiclav & 66.7 & 80.0 & 64.0 & 66.7 & 60.0 & 50.0 \\
\hline Cefalexin & 41.7 & - & 48.0 & - & 40.0 & - \\
\hline Cefazolin & 50.0 & - & 64.0 & - & 60.0 & - \\
\hline Cefuroxime & 58.3 & - & 64.0 & - & 80.0 & - \\
\hline Cefotaxime & 70.8 & - & 80.0 & - & 80.0 & - \\
\hline Cefoperazone & 70.8 & 100.0 & 76.0 & 100.0 & 80.0 & 75.0 \\
\hline Ceftazidime & 79.2 & - & 80.0 & - & 100.0 & 25.0 \\
\hline Sulperazone & 41.7 & 80.0 & 60.0 & 66.7 & 70.0 & 50.0 \\
\hline Cefepime & 70.8 & - & 76.0 & - & 80.0 & 25.0 \\
\hline Imipenem & 41.7 & 20.0 & 52.0 & 33.3 & 70.0 & 50.0 \\
\hline Meropenem & 66.7 & 60.0 & 80.0 & 33.3 & 60.0 & 75.0 \\
\hline Gentamicin & 62.5 & - & 80.0 & - & 80.0 & 25.0 \\
\hline Amikacin & 50.0 & - & 68.0 & - & 70.0 & - \\
\hline Ciprofloxacin & 83.3 & 100.0 & 88.0 & 100.0 & 100.0 & 75.0 \\
\hline Ofloxacin & 45.8 & 60.0 & 52.0 & 66.7 & 60.0 & 75.0 \\
\hline Furadonin & 66.7 & 100.0 & 44.0 & 100.0 & 60.0 & 75.0 \\
\hline Laevomycetin & 58.3 & 60.0 & 48.0 & 66.7 & 50.0 & 50.0 \\
\hline Biseptol & 33.3 & 60.0 & 48.0 & 66.7 & 40.0 & 25.0 \\
\hline Vancomycin & - & - & - & - & - & 25.0 \\
\hline Nitroxolin & 4.2 & - & - & - & 10.0 & - \\
\hline
\end{tabular}

Analyzing the antibiotic sensitivity of the Enterobacteriaceae in Group II, mention should be made of the dominating role of Ciprofloxacin (88.0\%), Cefotaxime (80.0\%), Ceftazidime $(80.0 \%)$, Meropenem (80.0 \%), Gentamicin (80.0\%), Cefoperazone $(76.0 \%)$, Cefepime $(76.0 \%)$, and Amikacin $(68.0 \%)$. However resistance to Ampicillin (80.0 \%), Laevomycetin (52.0\%), Oxacillin (52.0\%), Amoxicillin (40.0\%), Furadonin (40.0\%), Vancomycin

\section{References}

1. Belan Yu. B., Morozova T. A. Etiological aspects of urinary tract infections in children. Modern issues in science and education. 2008;2:12-16.

2. Otpuschennikova T. V. et al. A urologist's view on diagnosing and treating child pyelonephritis in outpatient-clinical pediatric practice. Doctor in charge. 2009;8:12-16.

3. Zaytsev V. M., Liflyandsky V. G., Marinkin V. I. Applied medical statistics. St.-Pb.; 2003. 432 p.

4. Zorkin S. N., Katasova L. K., Muzychenko Z. N. A view on antibiotic therapy in children with urological pathology. Doctor in charge. 2010;8:6-10.
(40.0\%), and Palin (40.0\%) was also present.

The children aged $3-5$ demonstrated high sensitivity of Enterobacteriaceae to Ceftazidime (100.0\%), Ciprofloxacin (100.0 \%), Cefuroxime $(80.0 \%)$, Cefotaxime $(80.0 \%)$, Cefoperazone $(80.0 \%)$, Cefepime (80.0\%), Gentamicin (80.0\%), Sulperazone (70.0\%), Imipenem (70.0\%), Amikacin (70.0\%), Amoxiclav $(60.0 \%)$, Cefazolin $(60.0 \%)$, Meropenem $(60.0 \%)$, Ofloxacin $(60.0 \%)$, and Furadonin $(60.0 \%)$. Yet, to Ampicillin (80.0\%), Oxacillin (50.0\%), Amoxicillin $(40.0 \%)$, Furadonin $(40.0 \%)$, and Laevomycetin $(40.0 \%)$ the isolated strains of the Enterobacteriaceae family were highly resistant, which prevented them from being used as initial antibiotics.

An analysis of the sensitivity shown by Str.faecalis to various antibiotics in Group I reveals a high number of strains susceptible to Cefoperazone (100\%), Ciprofloxacin (100\%), Furadonin (100\%), Ampicillin $(80 \%)$, Amoxiclav (80 \%), and Sulperazone (80\%). However, Str.faecalis was found to be highly resistant to other cephalosporins and aminoglycosides.

In Group II, Ampicillin, Cefoperazone, Ciprofloxacin, and Furadonin revealed a high level of activity towards all isolated strains of Str. faecalis; high resistance being registered to cephalosporins and aminoglycosides, though. The group aged 3 to $5 \mathrm{yrs}$ showed a sensitivity spectrum of Str. faecalis similar to that in the group of children under 1 year of age.

Conclusion. Therefore, the main pathogens for the community acquired UTI in children within their first 5 years are represented by the Enterobacteriaceae family, E.coli predominantly. The specific features of the UTI infectious agents in children (in Stavropol, Russia) included more frequent isolation of $\mathrm{Str}$. faecalis, which rated second in all the groups, while in the children aged aged 3 to 5 it was identified 1.8-2.9 times as often. The third most common was Candida spp. in the children under 1 year, Pseudomonas - in those aged 1-3, and Staph.aur. - in the group aged 3-5 yrs.

In view of the leading etiological significance of Enterobacteriaceae as well as of the obtained data on the pathogens susceptibility towards antibiotics, Amoxiclav, Cefotaxime, Cefoperazone, Ceftazidime, Cefepime, and Meropenem make a reasonable choice as empiric therapy for treating community acquired UTI in children up to 5 . The penicillins (Ampicillin, Amoxicillin, Oxacillin) and Laevomycetin should not be administered for empiric treatment due to the high-level resistance Enterobacteriaceae showed towards them.

5. Ignatova M. S. News of pediatric nephrology from International Congress of Nephrologists. Russian Newsletter of perinatal medicine and pediatrics. 2004;1:47-50.

6. Maltsev S. V., Safina A. I., Yudina E. V. Antibiotic therapy for pyelonephritis in children. Pediatrics. 2008;4:130-135.

7. Korovina N. A. et al. Protocol of diagnosing and treating pyelonephritis in children. M.; 2003. 71 p.

8. Safina A. I., Maltsev S. V. Structure of pyelonephritis agents in children. Pediatrics. 2005;4:23-29.

9. Kulakova E. N. et al. Spectrum of urinary tract infections in younger children. Volume of $\mathrm{V}$ Russian Congress on child nephrology. Voronezh; 2006. P. 125-126. 
10. Akram M., Shahid M., Khan A. U. Etiology and antibiotic resistance patterns of community-acquired urinary tract infections in J N M C Hospital Aligarh, India Ann. Clin. Microbiol. Antimicrob. 2007;4(6).

11. Hoberman A., Charron M., Hickey R. W. et al. Imaging

MONITORING SURVEY OF ANTIBIOTIC SENSITIVITY IN CHILD URINARY SYSTEM INFECTIOUS AGENTS (EXPERIENCE IN STAVROPOL)

MEDVEDEVA A. N., KALMYKOVA A. S.

The population subject to the study included 220 children aged 1 month - 5 years, with acute community acquired infections of the upper and lower urinary tract. As the data obtained showed, the major agents causing community acquired UTI in the first 5 years of age were bacteria belonging to the Enterobacteriaceae family, E. coli predominantly. The major features in the structure of the agents responsible for UTI development in the children of Stavropol (Russia) were higher detection frequency of Str.faecalis, which was the second most common in all the groups examined, while the children aged c 3-5 had it 1.8-2.9 times as often.

In view of the leading etiological significance of Enterobacteriaceae as well as taking into account the obtained data on the pathogens susceptibility towards antibiotics, Amoxiclav, Cefotaxime, Cefoperazone, Ceftazidime, Cefepime, and Meropenem make a reasonable choice as empiric therapy for treating community acquired UTI in children aged up to 5 . The penicillin antibiotics (Ampicillin, Amoxicillin, Oxacillin) and Laevomycetin should not be administered for empiric treatment due to the high-level resistance Enterobacteriaceae revealed towards them.

Key words: children, urinary tract infection, sensitivity, antibiotic drugs studies after a first febrile urinary tract infection in young children. N. Engl. J. Med. 2003;3(348):195-202.

12. Chakupurakal R., Ahmed M., Sobithadevi D. N., Chinnappan S., Reynolds T. Urinary tract pathogens and resistance pattern. J. Clin. Pathol. 2010;7(63):652-654.

\section{МОНИТОРИНГ ЧУВСТВИТЕАЬНОСТИ ВОЗБУАИТЕАЕЙ ИНФЕКЦИЙ МОЧЕВОЙ СИСТЕМЫ У АЕТЕЙ Г. СТАВРОПОАЯ}

A. H. MEABEAEBA, A. C. KA^MЫKOBA

Было обследовано 220 детей в возрасте от 1 месяца до 5 лет с острыми внебольничными инфекциями верхних и нижних мочевых путей. Установлено, что основными возбудителями внебольничных ИМС у детей первых 5 лет жизни являются представители семейства Enterobacteriaceae, главным образом E. coli. Основными особенностями структуры возбудителей ИМС детей г. Ставрополя являлось более частое выделение Str. faecalis, занимавшего второе место в структуре во всех группах, причем у детей с 3 до 5 лет он обнаруживался в 1,8-2,9 раза чаще.

Учитывая ведущую этиологическую роль Enterobacteriaceae и полученные результаты чувствительности, для эмпирической терапии внебольничной ИМС у детей до 5 лет целесообразно использовать амоксиклав, цефотаксим, цефоперазон, цефтазидим, цефепим, меропенем. Антибиотики из группы пенициллинов (ампициллин, амоксициллин, оксациллин) и левомицетин не следует назначать для эмпирической терапии в связи с высоким уровнем резистентности к ним Enterobacteriaceae.

Ключевые слова: дети, инфекция мочевой системы, чувствительность, антибиотики

\title{
DURATION OF LATENT PERIOD AND IRON DEFICIENCY DEVELOPMENT IN CHILDREN WITH CELIAC DISEASE
}

\author{
Klimov L. Ya. ${ }^{1}$, Kuryaninova V. A. ${ }^{1,2}$, Stoyan M. V. ${ }^{1,2}$, Asaturova D. V. ${ }^{1}$, \\ Gerasimenko E. S. ${ }^{1}$, Daguzhieva M. D. ${ }^{1}$
}

\section{Stavropol State Medical University, Russian Federation \\ 2 Philippsky Child Clinical Hospital, Stavropol, Russian Federation}

Klimov Leonid, MD, Associate Professor, Head of Faculty Pediatrics Department, Stavropol State Medical University tel.: 89289630261; e-mail: klimov_leo@mail.ru

Kuryaninova Victoria, Assistant of Propaedeutics of Children's Diseases Department, Stavropol State Medical University; tel.: 89282938069; e-mail: vichkak@mail.ru

Stoyan Marina, Assistant of Faculty Pediatrics Department Stavropol State Medical University;

tel.: 89282447990; e-mail: marina-stoyan@mail.ru

Asaturova Dayana, student of Pediatric Faculty, Stavropol State Medical University;

tel.: 89187914671; e-mail: miss.asaturova@mail.ru;

Gerasimenko Elena, Postgraduate student of Faculty Pediatrics Department, Stavropol State Medical University; tel.: 89886785715; e-mail: Drelena555@yandex.ru eliac disease in children is mostly associated with the development of a typical malabsorption syndrome, the neviitable parts of the latter being polyhypomicroelementosis and polyhypovitaminosis [3, 4, 15]. Obviously, the age at the onset of the disease typically depending on the time gluten was introduced into the diet, as well as the period prior to the verification of diagnosis (i.e. latent period), do have an impact on the patient body's iron supply [8]. In view of the high lability and vulnerability typical of iron metabolism in children, any disturbances in its 